\title{
PERBEDAAN INDIVIDU DALAM PROSES PEMBELAJARAN
}

\author{
Dalila Turhusna \& Saomi Solatun \\ Universitas Muhammadiyah Tangerang \\ dalila.turhusna@umt.ac.id,saomi.solatun@umt.ac.id
}

\begin{abstract}
In the learning process, the teacher is not enough just to deliver the material or what is commonly referred to as the transfer of knowledge. Because in learning there are several aspects of assessment that must be done by the teacher to students, namely cognitive aspects, affective aspects, and psychomotor aspects. Therefore, for the realization of learning objectives with optimal results, the teacher needs to recognize the characteristics of each student. We will find that individual variations are usually the result of interactions between bereditary and environmental influences simultaneously, which ultimately results in a unique buman being. Therefore as a teacher should be able to understand the characteristics and properties of each individual or student. Specific ways and methods and apply them directly in learning so that they know the differences of their students and how to overcome them in ways that are easily captured or understood by students.
\end{abstract}

Keywords: Individual Differences, Learning

\begin{abstract}
Abstrak : Dalam proses pembelajaran, guru tidak cukup hanya dengan menyampaikan materipelajaran saja atau yang biasa disebut dengan transfer ilmu. Karena di dalam pembelajaran terdapat beberapa aspek penilaian yang harus dilakukan guru terhadap siswanya yaitu aspek kognitif, aspek afektif, dan aspek psikomotor. Oleh karena itu, demi terwujudnya tujuan belajar dengan hasil yang optimal, maka guru perlu mengenal karakteristik masingmasing siswa. Kita akan menjumpai bahwa variasi individual biasanya merupakan hasil interaksi antara pengaruh keturunan dan pengaruh lingkungan secara bersamaan, yang akhirnya menghasilkan manusia yang unik. Oleh karena itu sebagai seorang guru hendaknya mampu memahami karakteristik maupun sifat-sifat dari masing-masing individu atau siswanya. Dengan cara maupun metode yang khusus dan mengaplikasikannya langsung dalam pembelajaran sehingga mengetahui perbedaan peserta didiknya dan bagaimana cara untuk mengatasinya dengan cara-cara yang mudah di tangkap atau di pahami siswa.
\end{abstract}

Kata Kunci : Perbedaan Individu, Pembelajaran

\section{PENDAHULUAN}

Setiap individu memiliki karakteristik yang berbeda-beda. Perbedaan secara umum disebabkan oleh dua factor, yakni factor bawaan dan factor lingkungan. Factor bawaan merupakan factor biologis yang diturunkan melalui pewaris genetic oleh orang tua. Factor lingkungan yang menyebabkan terjadinya perbedaan individual diantaranya sstatus social ekonomi orang tua, budaya, dan urutan kelahiran.

As-Sabiqun : Jurnal Pendidikan Islam Anak Usia Dini

Volume 2, Nomor 1, Maret 2020; 28-42

https://ejournal.stitpn.ac.id/index.php/assabiqun 
Perbedaan-perbedaan yang tampak diantaranya adalah perbedaan jenis kelamin dan gender, perbedaan kemampuan, perbedaan kepribadian, serta perbedaan gaya belajar, perbedaan tersebut sedikit banyak berpengaruh terhadap proses-proses pembelajaran. Perbedaan individu diantara anak didik merupakan hal yang tidak mungkin dihindari, karena hamper tidak ada kesamaan yang dimiliki oleh manusia kecuali perbedaan itu sendiri. Sejauh mana individu berbeda akan mewujudkan kualitas perbedaan mereka atau kombinasi-kombinasi dari berbagai unsur perbedaan tersebut. Setiap orang, apakah ia seorang anak atau seorang dewasa, dan apakah ia berada didalam suatu kelompok atau seorang diri, ia disebut individu. Individu menunjukan kedudukan seseorang sebagai orang perorangan atau perseorangan. Sifat individual adalah sifat yang berkaitan dengan orang perseorangan. Ciri dan sifat orang yang satu berbeda dengan yang yang lain. Perbedaan ini disebut perbedaan individu atau perbedaan individual. Maka "perbedaan" dalam "perbedaan individu" menurut landgren (1980) menyangkut variasi yang terjadi, baik variasi pada aspek fisik maupun psikologis. Dilingkungan pendidikan, ditemukan perbedaan individual anak didik cukup banyak, yang semuanya merupakan ciri kepribadian anak didik sebagai individu. Suharsimi arikunto (1986) melihat kepribadian anak didik itu mencakup aspek jasmani,agama, intelektual, social,etika, dan estetika.

\section{METODE PENELITIAN}

Penelitian ini merupakan penelitian dan pengembangan (Research and Development) dengan menggunakan langkah-langkah dari Sugiyono, namun hanya sampai pada tahap ketujuh, yaitu: 1) potensi dan masalah; 2) pengumpulan data; 3) desain produk; 4) validasi desain; 5) revisi desain; 6) uji kelayakan; dan 7) revisi produk. Penelitian dilakukan di sebuah MI Tarbiyah Islamiyah di batu ceper Tangerang dengan subjek guru kelas, dan siswa-siswi MI.

Data diperoleh melalui wawancara, observasi, dan studi dokumen. Analisa data yang digunakan dalam penelitian ini menggunakan analisi factual. 


\section{HASIL PENELITIAN DAN PEMBAHASAN}

Adapun hasil observasi yang telah observer lakukan yaitu sebagai berikut:

\begin{tabular}{|c|c|c|}
\hline \multirow{2}{*}{ Karakteristik } & \multicolumn{2}{|c|}{ Keterlaksanaan } \\
\hline & Ya & Tidak \\
\hline \multicolumn{3}{|l|}{ Perencanaan } \\
\hline Tersedia silabus dan RPP & $\sqrt{ }$ & \\
\hline RPP mencerminkan pembelajaran aktif & $\sqrt{ }$ & \\
\hline $\begin{array}{l}\text { Rumusan indikator/tujuan pembelajaran sesuai rumusan } \\
\text { SK/KD }\end{array}$ & $\sqrt{ }$ & \\
\hline $\begin{array}{l}\text { Indikator pembelajaran mengarah pada pengembangan } \\
\text { berpikir tingkat tinggi (C3; aplikasi, C4;analisis, C5; evaluasi, } \\
\text { C6;kreasi) }\end{array}$ & $\sqrt{ }$ & \\
\hline \multicolumn{3}{|l|}{ Pembelajaran } \\
\hline $\begin{array}{l}\text { Guru menggunakan model/pendekatan/metode/strategi } \\
\text { dalam proses belajar mengajar }\end{array}$ & $\sqrt{ }$ & \\
\hline $\begin{array}{l}\text { Penerapan model/pendekatan/metode/strategi yang } \\
\text { diterapkan oleh guru terlaksana dengan baik }\end{array}$ & $\sqrt{ }$ & \\
\hline Guru menggunakan media/sumber belajar dengan tepat & $\sqrt{ }$ & \\
\hline Tersedia alat peraga/media pembelajaran & & $\sqrt{ }$ \\
\hline $\begin{array}{l}\text { Guru menggunakan lingkungan untuk kegiatan } \\
\text { pembelajaran di luar kelas }\end{array}$ & & $\sqrt{ }$ \\
\hline Murid terlibat aktif dalam kegiatan pembelajaran & $\sqrt{ }$ & \\
\hline $\begin{array}{l}\text { Pembelajaran mendorong anak aktif berpikir kritis dan } \\
\text { kreatif }\end{array}$ & $\sqrt{ }$ & \\
\hline $\begin{array}{l}\text { Pembelajaran mendorong anak berinteraksi antar siswa- } \\
\text { guru dan siswa-siawa }\end{array}$ & $\sqrt{ }$ & \\
\hline Pembelajaran berkaitan dengan kehidupan nyata & $\sqrt{ }$ & \\
\hline $\begin{array}{l}\text { Pembelajaran memberikan kesempatan anak } \\
\text { mengemukakan pendapat }\end{array}$ & $\sqrt{ }$ & \\
\hline $\begin{array}{l}\text { Pembelajaran mendorong siswa menggunakan berbagai } \\
\text { indra }\end{array}$ & & $\sqrt{ }$ \\
\hline Pembelajaran melayani perbedaan individu siswa & & $\sqrt{ }$ \\
\hline \multicolumn{3}{|l|}{ Manajemen kelas } \\
\hline $\begin{array}{l}\text { Ada aturan atau tata tertib kelas yang diberlakukan dan } \\
\text { disepakati bersama }\end{array}$ & & $\sqrt{ }$ \\
\hline Penataan kelas mendorong anak untuk melakukan kegiatan & $\sqrt{ }$ & \\
\hline
\end{tabular}




\begin{tabular}{|l|c|c|}
\hline aktif & \multicolumn{2}{|c|}{} \\
\hline $\begin{array}{l}\text { Ada pembagian peran, tugas dan tanggung jawab dalam } \\
\text { kegiatan pembelajaran }\end{array}$ & $\sqrt{ }$ \\
\hline Penggunaan alat dan sumber belajar diatur dengan baik & $\sqrt{ }$ & \\
\hline Penilaian & $\sqrt{ }$ & \\
\hline Guru memantau perkembangan belajar siswa & $\sqrt{ }$ & \\
\hline $\begin{array}{l}\text { Guru memberikan umpan balik terhadap perkembangan } \\
\text { belajar siswa }\end{array}$ & $\sqrt{ }$ & \\
\hline Guru memberikan penghargaan (misalnya pujian) & \\
\hline Guru memajang hasil karya siswa (jika ada) & \\
\hline
\end{tabular}

Format lampiran masalah dan rekomendasi penyelesaian

\begin{tabular}{|l|l|}
\hline Permasalahan: & $\begin{array}{l}\text { Berdasarkan yang observer amati proses pembelajaran yang } \\
\text { dilakukan sudah sangat baik karena guru melibatkan siswa } \\
\text { secara aktif dalam proses pembelajaran akan tetapi tidak } \\
\text { semua siswa aktif dalam pembelajarn masih ada beberapa } \\
\text { siswa yang sibuk dengan urusannya masing-masing dan } \\
\text { kurang memperhatikan guru. }\end{array}$ \\
\hline Akar masalah: & $\begin{array}{l}\text { Ketika dijelaskan oleh gurunya ada anak yang berbagai } \\
\text { macam karakternya. Ada yang cepat tangggap dalam } \\
\text { memahami dan ada anak yang kurang tanggap dalam } \\
\text { memahaminya Dari segi tulisan siswa laki-laki dan } \\
\text { perempuan sudah cukup rapi dan bagus. }\end{array}$ \\
\hline $\begin{array}{l}\text { Rekomendasi } \\
\text { langkah } \\
\text { penyelesaian: }\end{array}$ & $\begin{array}{l}\text { adanya kesan menyamaratakan siswa, sedangkan kita ketahui } \\
\text { tingkat kecerdasan dan pemahaman siswa berbeda-beda } \\
\text { sehingga disini guru dituntut untuk lebih memahami siswanya } \\
\text { dan memiliki kreatifitas yang baik. }\end{array}$ \\
\hline
\end{tabular}

Adapun kegiatan yang dilakukan selama proses pembelajaran dibagi menjadi tiga kegiatan yaitu kegiatan awal, kegiatan inti dan kegiatan akhir (penutup) yang akan diuraikan sebagai berikut.

1. Kegiatan awal

Pada saat guru sudah ada di dalam ruang kelas untuk memulai pembelajaran, terlebih dahulu peserta didik menyiapkan, memberi salam 
kepada guru dan berdo'a bersama-sama yang dipimpin oleh ketua kelas. Kemudian guru mengabsen siswa, menanyakan kabar siswa dan mempersilahkan siswa mempersiapkan buku dan alat tulisnya masing-masing, setelah itu guru menginformasikan kepada siswa tentang topik dan tujuan pembelajaran yang akan dicapai dari kegatan pembelajaran. setelah itu guru menanyakan kesiapan siswa dalam menerima pembelajaran, setelah semua siswa telah siap untuk belajar maka guru pun mulai masuk kegiatan inti.

2. Kegiatan inti

Dalam kegiatan pembelajaran guru menggunakan metode pembelajaran ceramah, pemberian tugas dan tanya jawab. Langkah pertama guru memberikan penjelasan kepada siswa dengan singkat dan dengan menggunakan bahasa yang mudah dipahami oleh siswa. Dalam penjelasan yang disampaikan, guru mengaitkannya dengan kehidupan sehari-hari yang dekat dengan lingkungan siswa dan mencontohkannya dari peristiwa yang terjadi secara nyata. Sesekali guru bertanya kepada siswa mengenari materi yang diajarkan dan memberikan pujian kepada siswa ketika siswa berhasil menjawab pertanyaan yang diajukan oleh guru. Dan guru juga memberikan kesempatan kepada siswa untuk bertanya ketika masih ada yang kurang dipahami.

Setelah guru memeberikan penjelasan dan setelah proses tanya jawab guru memberikan tugas kepada siswa dengan menuliskan pertanyaannya di papan tulis dan mengistruksikan siswa untuk mengerjakannya dalam waktu 30 menit. setelah siswa mengerjakan tugasnya guru menyurus semua siswa untuk mengumpulkan tugasnya untuk diperiksa dengan cara pemberian skor 0-100. Setelah guru memeriksa pekerjaan siswa guru membagikannya kembali kepada masing-masing siswa.

3. Kegiatan akhir (penutup)

Pada kegiatan penutup guru dan siswa menyimpulkan materi pelajaran kemudian guru memberikan tugas kepada siswa untuk dikerjakan di rumah dan guru menginformasikan kepada siswa materi yang akan dipelajari pada pertemuan berikutnya, serta mengingatkan siswa untuk mengulang materi 
yang telah dipelajari dan membaca materi yang akan dipelajari pada pertemuan selanjutnya.

\section{PEMBAHASAN}

\section{Implikasi perbedaan individu}

1. Perbedaan individu

Perbedaan individual diantara anak didik merupakan hal yang tidak mungkin dihindari, karena hamper tidak ada kesamaan yang dimiliki oleh manusia kecuali perbedaan itu sendiri. Sejauh man individu berbeda aaakan mewujudkan kualitas perbedaan mereka atau kombinasi-kombinasi dari berbagai unsur perbedaan tersebut. ,

Setiap orang, apakah ia seorang anak atau seorang dewasa, dan apakah ia berada didalam suatu kelompok atau seorang diri, ia disebut individu. Individu menunjukan kedudukan seseorang sebagai orang perorangan atau perseorangan. Sifat individual adalah sifat yang berkaitan dengan orang perseorangan, berkaitan dengan perbedaan individual perseorangan. Ciri dan sifat orang yang satu berbeda dengan yang lain. Perbedaan ini disebut perbedaan individu atau perbedaan individual. Maka "perbedaan" dalam "perbedaan individual" menurut Landgren (1980) menyangkut variasi yang terjadi, baik variasi yang aspek fisik maupun psikologis.

2. Perbedaan biologis

Perbedaan anak didik dalam aspek biologis ini tidak bisa dianggap tidak penting. Kesehatan anak didik adalah aspek lain yang patut mendapat perhatian dalam hal ini. Aspek biologis yang terkait langsung dengan penerimaan pelajaran dikelas adalah kesehatan mata dan telinga. Anak didik yang memiliki masalah tertentu dalam penglihatan dan pendengarannyaa akan mengalami masalah tersendiri dalam menerima pelajaran. Perbedaan biologis aanak didik secara umum terkadang menimbulkan perlakuan yang berbeda dari pendidik atau guru.sebagian guru memasukan unsur biologis dalam penilaianya terhadap siswa. 
Berdasarkan ide-ide pokok tentang tingkah laku manusia tersebut, freud kemudian membedakan kepribadian menjadi aatas tiga unit mental aatau struktur psikis, yaitu id, ego, dan superego.

Id merupakan aspek biologis kepribadian karena berisikan unsur -unsur biologis, termasuk di dalamnya dorongan-dorongan dan implus-implus instnkif yang lebih dasar. Id merupakan realitas psikis yang sesungguhnya karena hanya merupakan dunia batin/ dunia subjektif.

Ego merupakan aspek psikologis kepribadian karena timbul dari kebutuhan organisme untuk berhubungan secara baik dengan dunia nyata dan menjadi perantara antara kebutuhan instinkif organisme dengan keadaan lingkungan.

Superego adalah aspek sosiologis kepribadian karena merupakan wakil nila-nilai tradisional dan cita-cita masyarakat sebagaimana yang ditafsirkan orangtua kepada anak-anaknya melalui berbagai perintah dan laarangan.

3. Perbedaan psikologis

Perbaadaan psikologis pada siswa mecakup perbedaan dalam minat, motivasi, dan kepribadian. Ketiga factor psikologis ini berkolerasi positif dengan hasil belajar yang dicapai. Dalam kondisi minat yang besaar terhadap pelajaran, motivasi yang tinggi untuk belajar, dan kemampuan memori yang maksimal, maka hasil belajar yang dicapai juga akan maksimal.

Perbedaan psikologis ini dapat dimanfaatkan oleh guru daalam pengelolaan kelas, terutama dalam penempatan anak di tenpat duduk dan pengelompokan. Anak yang memiliki minat dan motivasi yang rendah sebaiknya dimasukan kedalam kelompok anak yang memiliki minat dan motivasi yang tinggi agar anak yang kurang termotivasi itu menjadi lebih termotivasi.

4. Perbedaan inteligensi

Penelitian-penelitian tentang konsepsi perbedaan individual yang banyak dilakukan diantaranya adalah perbedaan inteligensi, dan bagaimana perbedaan dalam inteligensi tersebut berpengaruh paada perbedaan prestasi. 
Perbedaan inteligensi ini terutama berkaitan dengan perolehan belajar. Menurut ackerman (dalam Berliner \& calfee, ) proses perolehan belajar ini tersusun dari tiga fase yang masing-masing membutuhkan kemampuan intelektual yang berbeda-beda, yaitu fase kognitif, asosiatif, dan otonomi.

Salah satu ciri kematangan intelektual siswa adalah kemampuannya mentoleransi ketidakpastian, menahan persetujuan, kemampuan untuk menghadapi kontradiksi, serta mengakui manfaat atas konsep dan pendapat yang berlawanan tanpa skeptisme dan rivalitas. Orang yang sudah matang intelektualnya tidak akan mengembangkan sikap antagonistic ketika terjadi perbedaan pendapat.

5. Perbedaan bakat

Meski istilah bakat dan inteligensi sering digunakan dengan maksud yang sama, namun bakat hanyalah salah satu karakteristik inteligensi. Menurut Bingham mendefinisikan bakat sebabai sebuah kondisi atau rangkaian karakteristik yang dianggap sebagai gejala kemampuan seorang individu untuk memperoleh melalui latihan sebagian pengetahuan, keterampilan, atau serangkaian respons sperti kemampuan berbahasa, kemampuan music dan sebagainya.

Daftar berikut ini dimaksudkan untuk membantu orang tua dan guru dalam mengenali bakat intelektual di balik"kecacatan" anak

a. Siswa berbakat dengan penurunan visual

- Belajar cepat

- Memori superior

- Superior dalam kemampuan berkomunikasi verbal dan penguasaan kosa kata

b. Siswa berbakat dengan penyandang cacat fisik

- Pengembangan keterampilan kompensasi

- Mengesankan menyimpan pengetahuan

- Keterampilan akademik tingkat tinggi

- Luar biasa dalam keterampilan pemecahan masalah 
c. Siswa berbakat dengan gangguan pendengaran

- Kemampuan membaca berkembang lebih awal

- Memori yang luar biasa

- Cepat menangkap ide-ide

- Kemampuan penalaran yang tinggi

\section{Pertumbuhan dan perkembangan manusia}

Dalam pribadi manusia, baik yang jasmaniah maupun yang rohaniah, tetdapat dua bagian yang berbeda sebagai kondisi yang menjadikan pribadi manusia berubah menuju kearah kesempurnaan. Adapun dua bagian kondisional pribadi manusia itu meliputi:

a. Bagian pribadi material yang kuaantitatif, dan

b. Bagian pribadi fungsional yang kualitatif.

Kenyataan itu lah yang melahirkan perbedaan konsep antara pertumbuhan dan perkembangan. Adapula hukum-hukum yang mengatur pertumbuhan dan perkembangan.

1. Tempo pertumbuhan adalah tidak sama

Urutan atau sequence pertumbuhan tidak bergerak dalam waktu yang konstan. Disamping itu, indicator-indikator tidak muncul dalam saat-saat yang teratur. Ada saat-saat dimana pertumbuhan berlangsung cepat, dan ada pula saatsaat dimana pertumbuhan berlangsung lambat. Selama masa bayi dan prasekolah, anak mengalami pertumbuhan pesat dan indicator-indikator kemantangan muncul silih berganti secara cepat. Pada masa sesudah prasekolah, pertumbuhan anak menjadi lambat. Ini tidak berarti, bahwa perubahan-perubahan penting tidak berlangsung.

2. Taraf perkembangan berbagai aspek pertumbuhan adalah berbeda-beda

Tidak semua aspek pertumbuhan seperti fungsi jasmani, bahasa, dan kapasitas intelektual berkembang dengan taraf yang sama dalam waktu yang sama. 
Sebagai contoh, orang tua sering khawatir berhubung anak-anaknya yang berumur satu tahun dapat menyebutkan tiga atau sampai tujuh kata, tetapi pada umur tiga atau empat tahun berikutnya jarang sekali menyebutkan kata-kata baru, bahkan beberapa kata yang pernah dikuasai menjadi terlupakan,. Perkembangan bahasa anak tidak sama cepat dengan perkembangan fungsi jasmani, pada suatu ketika perkembangan anak mengalami kelambatan akibat adanya perkembangan pesat pada fungsi-fungsi jasmaninya.

3. Kecepatan serta pola pertumbuhan dapat dimodifikasi oleh kondisi-kondisi didalam dan diluar badan.

Kondisi-kondisi lingkungan internal seperti gizi, aktivitas, istirahat, tekanan jiwa, kesehatan jasmani, dan sebagainya sangat menentukaan kecepatan pertumbuhan serta keterlibatan potensi-potensi pertumbuhan pada individu.

Lingkungan dimana individu hidup yang jelek dan kurang bersih akan mengganggu kesehatan, lingkungan social yang kacau dan kurang toleran akan mengganggu ketenangan jiwa, lingkungan yang sibuk dan menentang aktivitas akan mengurangi istirahat.

4. Masing-masing individu tumbuh menurut caranya sendiri yang unik.

Tidak semua individu mengalami pertumbuhan dengan cara yang sama. Ini terbukti, bahwa beberapa ada yang tinggi, beberapa yang lain adalah pendek, ada yang gemuk dan ada pula yang kurus, ada yang hitam da nada yang putih, ada yang tampan da nada pula yang kurang tampan, dan sebagainya.

Keunikan pertumbuhan pada masing-masing individu itu antara lain disebabkan oleh:

- Perbedaan kondisi lingkungan internal

- Perbedaan kondisi lingkungan eksternal

- Perbedaan materi herediter

- Perbedaan aktivitas

- Perbedaan kondisi fisiologis seperti cacat-cacat fisik 
- Perbedaan usia

- Perbedaan jenis kelamin, dan

- Perbedaan hasil belajar.

\section{Teori pembelajaran dan perbedaan gaya belajar}

A. Perspektif dan teori pembelajaran

Mengkaji tentang teori-teori pembelajaran sangat bermaanfaat bagi guru untuk mempertimbangkan berbagai teori belajar untuk keperluan mengajar, mengidentifikasi prinsip-prinsip pembelajaran, dan memahami bagaiman perbedaan individu memengaruhi proses belajar. Ada berbagai teori tentang bagaimana siswa belajar. Berikut ini adalah beberapa teori-teori pembelajaran:

1. Teori simulasi sensorik

Secara tradisional simulasi sensorik dibangun atas premis dasar bahwa pembelajaran yang efektif kterjadi ketika indera distrimulasi. Laird mengutip penelitian yang menemukan bahwa sebagian besar pengetahuan yang dimiliki oleh orang dewasa $(75 \%)$ adalah belajar melalui melihat. Mendengar adalah sentuhan berikutnya yang efektif (sekitar 13\%), indera yang lain, seperti penciuman dan rasa memberi konstribusi sebesar 12\% dari apa yang kita tahu. Dengan merangsang indera, terutama dalam arti visual, belajar dapat ditingkatkan.

Teori ini mengatakan bahwa jika multi-indera yang distimulasi, akan diperoleh hasil belajar yang besar lagi. Sitimulasi atas indera dicapai melalui berbagai warna yang lebih besar, tingkat volume, pernyataan yang kuat, fakta yang disajiakan secara visual, serta penggunaan berbagai tekhnik dan media.

\section{Teori penguatan}

Teori ini dikembangkan oleh psikologi aliran behavioris, terutama oleh B.F. skinner awal abad ke-20. Skinner percaya bahwa perilaku adalah fungsi dari konsekuensinya. Siswa akan mengulangi prilaku yang diinginkan jika penguatan positif (konsekuensi yang menyenangkan) menyertai prilaku. 
Penguatan positif atau "imbalan" dapat mencakup penguatan verbal seperti "bagus", "bagus sekali", “sukses", “sukses selalu”. Penguatan positif ini juga dapat berupa penghargaan lebih nyata, seperti sertifikat diakhir kursus, piagam sebagai bukti peringkat, perayaan khusus, dan sebagainya. Penguatan negative juga dapat memperkuat prilaku dan mengacu pada penghentian atau menghindari kondisi negative sebagai konsekuensi dari perilaku tersebut.

3. Teori fasilitasi

Teori fasilitasi mengharuskan guru menjadi fasilitator belajar yang sesungguhnya. Guru fasilitatif bercirikan sebagai berikut:

a. Terbuka terhadap kritik, saran dan konstruksi berpikir dari guru-guru lain,

b. Lebih mampu mendengarkan peserta didik, terutama terhadap perasaan mereka.

c. Cenderung banyak memberikan perhatian dan berinteraksi dengan siswa selama proses pembelajaran.

d. Cenderung menerima umpan balik, baik psotif maupun negative, dan menggunakan nya sebagai wawasan konstruktif dalam diri dan prilaku siswa.

e. Mendorong siswa bertanggung jawab atas pembelajaran mereka sendiri.

4. Teori pengalaman belajar

Hasil penelitian kolb membuktikan siswa belajar dalam empat cara dengan kemungkinan mengembangkan satu cara belajar lebih intensif dibandingkan dengan cara lain. Seperti ditunjukan dalam "siklus pengalaman belajar" model diatas, pembelajaran adalah:

a. Melalui pengalaman konkret

b. Melalui observasi dan refleksi

c. Melalui konseptualisasi abstrak

d. Melalui percobaan aktif 


\section{B. Teori perbedaan gaya belajar}

Siswa memiliki gaya belajar yang berbeda, kalau pun ada kesamaan, dan memang banyak yang sama cara belajarnya, terjadinya hanyalah kebetulan, gagasan bahwa orang belajar dengan cara yang berbeda telah dieksplorasi melalui penelitian pendidikan selama beberapa dekake terakhir. Kolb, salah seorang ilmuwan dan peneliti yang paling berpengaruh dalam penelitian mengenai gaya belajar, menemukan bukti bahwa siswa umumnya mulai dengan gayayang mereka sukai dalam siklus pengalaman belajar. Hasil penelitian kolb dikembangkan oleh honey dan mumford, dimana mereka berhasil mengidentifikasi empat gaya belajar, seperti berikut ini:

- Gaya aktivis, belajar dengan menikmati pengalaman itu sendiri

- Gaya reflector, belajar dengan cara menghabiskan banyak waktu dan usaha untuk merefleksi laksana cermin bayang.

- Gaya teoritisian, belajar dengan cara membuat koneksi atau merumuskan gagsan abstrak dari pengalaman

- Gaya pragmatis, belajar dengan menikmati kegiatan belajar yang hasilnya langsung dapat dimanfaatkan.

1. Teori belajar aksi

Belajar aksi adalah pendekatan yang menghubungkan dunia pendidikan dengan dunia kerja melalui proses reflektif dalam kelompok-kelompok kecil pembelajaran kooperatif. Inilah yang dikenal sebgai "belajar aksi secara berkelompok" atau "set belajar aksi" set atau kelompok bertemu secara teratur untuk mendiskusikan atau mempelajari isu-isu kehidupan nyata dari individu anggota dengan tujuan untuk belajar dan dari satu sama lain.

2. Teori pembelajaran langsung teori pembelajaran langsung juga dikenal pembelajaran eksplisit adalah metode sistematis untuk menyajikan materi dalam langkah keccil, kemudian "berhenti" untuk memberikan 
pemahaman, keberhasilan, dan partisipasi siswa dalam proses
pembelajaran

C. Cara Mengatasi Variasi Individual dalam Pembelajaran

Variasi individual yang terjadi dalam belajar di sekolah meskipun merupakan suatu hal yang wajar sebagai dampak kondisi individu siswa yang berbeda-beda, namun demikian jangan dibiarkan oleh guru. Guru harus berupaya untuk mengatasi kondisi variasi individual dalam proses belajar siswa tersebut, sebab jika dibiarkan sudah pasti akan terjadi perbedaan hasil belajar antara siswa secara mencolok, yang akibatnya gurunya juga dinilai tidak berhasil dalam mengajar, karena rata-rata pencapaian hasil belajar siswanya rendah. Oleh karena itu untuk mengatasi variasi individual dalam belajar di sekolah yang berdasarkan sistem pengajaran klasikal tersebut pertama kali harus diatasi dengan menyelenggarakan sistem pengajaran individual yaitu cara melaksanakan pengajaran yang berupaya memperhatikan atau melayani setiap individu siswa sesuai dengan tingkat kemampuannya.

\section{KESIMPULAN}

Manusia adalah mahluk yang dapat dipandang dari berbagai sudut pandang. Sejak ratusan tahun sebelum masehi, manusia telah menjadi obyek filsafat, baik obyek formal yang mempersoalkan hakikat manusia maupun obyek material yang mempersoalkan manusia sebagai apa adanya manusia dengan berbagai kondisinya. Perbedaan individu, diantaranya perbedaan kognitif, perbedaan kecakapan bahasa, perbedaan kecakapan motorik, perbedaan latar belakang, perbedaan bakat, perbedaan kesiapan belajar, perbedaan tingkat pencapaian, perbedaaan lingkungan keluarga, latar belakang budaya dan etnis, dan faktor pendidikan. 


\section{DAFTAR PUSTAKA}

M. Dalyono, 2015,psikologi pendidikan,Jakarta:PT. Rineka Cipta

Dra.Desmita,M.Si,2014,psikologi perkembangan peserta didik,Bandung:PT.Remaja rosdakarya

Prof. DR. Sudarwan Danim, Dr. H. Khairil, 2011,psikologi pendidikan,Bandung: Alfabeta

John W. Santrock,2014,psikologi pendidikan,jakarta:Salemba humanika

Nyayu Khodijah, 2014,psikologi pendidikan,Jakarta: PT.Raja grafindo persada 